\title{
Una lectura del mito de Narciso: tragedia y fotografía*
}

\author{
Julián David Romero Torres**
}

Recibido: 14 de febrero de 2012 Evaluado: 8 de marzo de 2012 Aceptado: 17 de abril de 2012

\section{RESUMEN}

Este texto indaga por la relación posible entre la fotografía y el mito de Narciso. Para este asunto se presenta, en primera instancia, la narrativa de la leyenda de "Narciso y Eco", escrita por Ovidio, al igual que una breve referencia a otras escrituras clásicas de esta. Así, se construye un diálogo entre el mito y la naturaleza de la fotografía, enfatizando en la práctica fotográfica familiar, en un análisis de los puntos de articulación y quiebre. La correspondencia entre el espejo y la fotografía es uno de esos lugares de disertación en donde germina la discusión, como también el engranaje de pares entre identidad-alteridad, sujeto-objeto y apariencia-realidad. Se finaliza con la apuesta del psicoanálisis, en tanto despliega una visión del narcisismo, que como componente medular de la actual disertación conecta al sujeto que se autoerotiza con el empalme del "yo fotográfico", nueva categoría que se funda en este texto y amerita posteriores desarrollos.

Palabras clave: Narciso, fotografía, apariencia, realidad. 


\section{A reading of the Narcissus myth: tragedy and photography}

\section{Abstract}

This text inquires on the possible relation between photography and the Narcissus myth. For this matter it presents, firstly, the narrative of the legend of "Narcissus and Echo", written by Ovid, as well as a brief reference to other classic literature thereof. Thus, a dialogue is built between the myth and the nature Aceptado: 17 de abril de 2012 of the photography, emphasizing in the familiar photographic practice, in an analysis of the articulation and breaking points. The correspondence between mirror and photography is one of the dissertation places where discussions sprout, as well as the sequence of pairs between identity-otherness, subject-object and appearance-reality. It is concluded with the commitment of psychoanalysis, as it displays a vision on narcissism, which as core component of the current dissertation connects the individual who auto-eroticizes with the connection "photographic I", a new category based on this text and that is worthy of further developments.

Keywords: Narcissist, photography, appearance, reality. 


\section{INTRODUCCIÓN}

Constituida por imágenes,

la cultura urbana es como un salón de espejos cuyos reflejos se reproducen hasta el infinito. Frente a la perfección

de sus imágenes tecnológicas, la ciudad y el cuerpo se convierten en ruinas $[\ldots]$

Vivimos en un paisaje transitorio, donde nuevas ruinas se amontonan constantemente sobre otras.

En medio de estas ruinas nos buscamos a nosotros mismos.

Olalquiaga

Una de las tragedias míticas romanas que ha dejado mucho de qué hablar, pensar, reflexionar es "Narciso y Eco", escrita por el romano Publius Ovidius Naso, más conocido como Ovidio, incluido en el libro Metamorphoseon, Las metamorfosis, en el que se habla de un hombre que nació de las entrañas de una ninfa de cabellos azules -Liríope-, la cual fue envuelta por la "sinuosa corriente" del río Cefiso, que la atrapó en la profundidad de sus aguas, y en su perfidia turbulenta abusó sexualmente de ella. De este tortuoso, delirante y acuoso acontecimiento nace Narciso, que, rebosante de hermosura, hace olvidar a su madre el deseo insatisfecho de una maternidad no anhelada.

La madre, al consultarle a Tiresias, el gran sabio de los oráculos, acerca del nacimiento de su hijo y, sobre todo, de su inminente destino, descarga la sentencia que le tienen preparados dioses y parcas: “Llegaría a ver los largos días de una vejez avanzada [...], si no llega a conocerse". La condena dictada por el oráculo consistía en que la vida de Narciso podría ser de largo aliento y pasividad; si de ninguna manera se encontrase directamente con su propia belleza y si por algunos avatares de la contingencia del destino mirara de frente su imagen, se consumaría en la muerte, sentencia que no determina absolutamente el futuro, sino que permite un margen de salvación. Nadie entendió las misteriosas palabras del oráculo, entrando estas en la indiferencia que solo le da el pasar de los años.

La infancia y la juventud de nuestro Narciso se debatían entre la tierna belleza de su cuerpo, rostro y cabellos, y una soberbia enérgica y atractiva, elementos que le impidieron conocer algún ser en el mundo que le tocase el corazón; simplemente se dedicaba al pastoreo. En una de las jornadas regulares de trabajo tuvo un encuentro particular con una ninfa. Esta, la resonante Eco, con su cuerpo y su voz, fue condenada, a causa de sus ligeros amoríos y constante charlatanería con los dioses, a repetir entre muchas palabras únicamente las últimas; sustraída a corear el final de las frases, devuelve las palabras que ha oído incansablemente; su cuerpo, desperdigado en infinidad de partes irrigadas por muchos lugares de Gea. Eco, al ver a Narciso, se enamora profundamente de él, lo sigue entre los montes sin ser vista, lo observa detenidamente entre los sotillos; no obstante, Narciso escucha... presiente que alguien lo está siguiendo y pregunta: “¿Hay alguien?”. Eco responde: "¡Alguien! jalguien!". Se queda atónito y dice: “iVen!”, y después de quedar sorprendido por escuchar una repetición sobre la marcha de sus palabras exclama: “iAquí, reunámonos!", y con el mayor placer Eco resuena: “Unámonos! junámonos!”, saliendo disparatada y henchida de placer a estrechar sus brazos en el cuello de su idilio platónico. Encuentra así el infortunio de la 
huida y desaprobación de Narciso, diciéndole: "¡Quita esas manos, no me abraces! ¡Antes morir que puedas tú tenerme!”. De tan desagraciado encuentro solo quedó un leve sonido: “¡Puedas tú tenerme!”, y desde entonces la ninfa vive refugiada en cuevas solitarias con su cuerpo evaporado; difuminados sus huesos en piedras se la encuentra en parajes solitarios perdurando únicamente su voz, su inacabada duplicación sonora en afligido efecto Dopler.

Narciso, un personaje que nunca se había enamorado de ser alguno y rechazando aquellos que se enamoraban de él, recibió una maldición en la voz de la diosa Némesis: “Así ame él, ojalá; así no consiga al objeto de sus deseos" (Ovidio, 2007, p. 133). Cuenta Ovidio que había en los bosques una fuente de agua totalmente apacible y cristalina, de una quietud asombrosa nunca antes tocada por ningún pastor, animal, ni nenúfar alguno, ni siquiera la rama de un árbol había enturbiado el grandioso espejo de agua, hasta llegar a tal punto que el bosque que lo rodeaba permitía que su superficie no fuese atravesada por los rayos del sol. Este fue el lugar indicado para que Narciso descansara de su extenuante jornada de caza:

\section{Y mientras ansía calmar la sed, nació otra sed; y mientras bebe, cautivado por el reflejo de la belleza que está viendo, ama una esperanza sin cuerpo; cree que es cuerpo lo que es agua. Se extasía ante sí mismo y sin moverse ni mudar el semblante permanece rígido como una estatua tallada en mármol de Paros (Ovidio, 2007, p. 133).}

Sintiendo que la imagen que acaba de ver es la de un ser lejano y tangible, sumerge sus brazos para tocarlo y besarlo; "no sabe qué es lo que ve, pero lo que ve le quema, y la misma ilusión que engaña sus ojos, lo excita" (Ovidio, 2007, p. 133), y de manera colosalmente crédula intenta atrapar en prófugas imágenes. Sin saberlo estaba cumpliendo con los designios del oráculo: mientras contemplaba la engañosa imagen -se conocía a sí mismo- se agotaban los cortos instantes de vida, "se muere por sus propios ojos" (Ovidio, 2007, p. 134), dirigiendo clamores de desgarrado amor a la imagen que se le hace lejana: "Creerías que es posible el contacto; es muy pequeño el obstáculo a nuestro amor" (Ovidio, 2007, p. 134); y después de haber comprobado que sus movimientos eran los mismos que se reflejaban en el agua, se percata de que es él mismo su propio reflejo: la imagen que se manifiesta ante sus ojos le produce tantos sentimientos encontrados que se ha comprendido en sí, se ha enamorado de sí e implora: “Que pueda yo al menos contemplar lo que no me es posible tocar, y dar así pábulo a mi desdichada locura" (Ovidio, 2007, p. 135). Este profundo dolor le quita paulatinamente las pocas fuerzas del corto tiempo que le queda de vida, y frente a su imagen, viendo cómo sus lágrimas le rosaban los pómulos y rodaban hasta intranquilizar la quietud del agua, difuminándose su rostro en las ondas que produjo las gotas que cayeron de aflicción, se rasgó las vestiduras y su pecho relució en la fuente:

\footnotetext{
Apenas vio esto en el agua, de nuevo cristalina, no soportó más, sino que, como suele fundirse la rubia cera a fuego lento, o la escarcha de la mañana al sol naciente $[. .$.$] va siendo devora-$ do poco a poco por aquel oculto fuego (Ovidio, 2007, p. 135).
}

Es así como Eco, hasta el final, calca las últimas palabras de Narciso, envuelto entre el dolor de la muerte lenta y la inaprehensión de su único amor. Curiosamente, todos los que en algún momento lo amaron, lloraron 
su muerte, y los sonidos de los lamentos se escuchaban en el eco del bosque. Cuando fueron a recuperar el cuerpo inhabitado, no encontraron rasgo alguno; en vez de cuerpo, encontraron una flor amarilla, con pétalos blancos, una flor grande y solitaria que lleva inscrito el nombre de Narkisos ${ }^{1}$.

Esta historia trágica tiene la particularidad de ser contada en varias versiones clásicas pertenecientes al periodo griego y grecorromano. Veamos.

Pausanias, en sus viajes por Beocia, cuenta que Narciso tenía un único amor: su hermana gemela, hermosa, por ende, como él, a la que ama profundamente; al enterarse de su muerte y no poder enfrentar tal tribulación, melancólicamente se hunde en su propia imagen que le da el agua, suicidándose, volviendo al padre, al río que copuló violentamente a la ninfa: nace del agua y a ella regresa sin modificación en el ciclo. Podemos entender el interés racionalista de Pausanias:

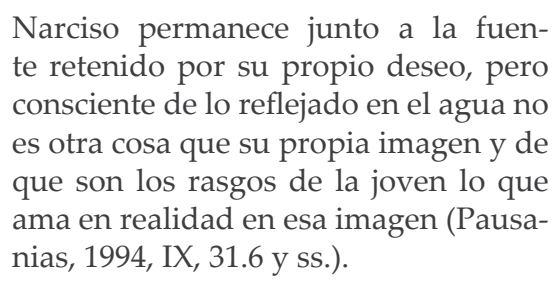

Otra versión, a manos del mitógrafo Conón, narra cómo Narciso, al ser tan bello, hace enamorar a hombres, mujeres, ninfas y mortales, entre estos Aninias, un pobre mortal que, como tantos, cayó en las redes que nunca había lanzado Narciso, quien no encontraba ni siquiera una brizna de simpatía en los otros, no había campo sino para sí mismo. Es así como este envía una espada a Aminias para que demuestre su amor sacrificando su propia vida, y así lo hiciere exclamando a Eros que se condene a Narciso, que envuelto en la confusión de su imagen que fulgurara en el agua se suicide al enamorarse de sí mismo y de su sangre chorreada por la tierra germinase una flor que llevara su nombre. "En esta versión de Conón, Narciso muere consciente de que su muerte es un castigo justo por su hibrys, por su violenta arrogancia" (Caballero, 2003, p. 112).

Se conocen diversos relatos del mito. El más conocido y más elaborado, por sus detalles y complejidad, es el escrito por Ovidio, que conserva los elementos esenciales de las dos narraciones anteriormente descritas: la fogosidad de ver su imagen en el agua, su muerte producto de lo que se denomina en psicoanálisis "narcisismo" (líneas más adelante se desarrolla) y el nacimiento de una flor producto de su muerte. Igualmente, es mérito en Ovidio el que se le muestre la ilusión de "Otro" a Narciso en dos momentos: Eco repite sus palabras y rechaza a ese otro materializado en sonido, y el agua destella su imagen sin saber que es él mismo, hasta que intenta tocar su doble.

Es de esta manera como se resaltan los puntos de encuentro y lo significativo que sobresale para ser un texto clásico y perdurar en el tiempo, en las lecturas, en las interpretaciones, en los juegos del pensamiento:

Clásico es aquel libro que una nación o un grupo de naciones o el largo tiempo han decidido leer como si en sus páginas todo fuera deliberado, fatal, profundo como el cosmos y capaz de interpretaciones sin término [...] prometen una larga inmortalidad (Borges, 2011, p. 382).

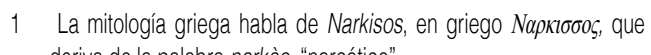
deriva de la palabra narkào, "narcótico". 
Es por eso que este mito nos suscita una suerte de designio o conjuro, tal vez condena o tragedia para la fotografía, para ese deseo de vernos, adularnos en la imagen, en el espejo de agua.

\section{LA GRAFía DE LA LUZ}

¿Para qué intentas en vano atrapar fugitivas imágenes? [...]

Esa sombra que estás viendo es el reflejo de tu imagen.

No tiene entidad propia; contigo vino $y$ contigo permanece.

Ovidio

Al poner en el lugar de Narciso a la familia o, más bien, a las diversas formas de organización familiar actuales que practican la fotografía de manera habitual -siendo una de sus vivencias, rituales o pragmatismos cotidianos-, y al entablar un diálogo con la tragedia clásica, podemos extrapolar lo siguiente. Mientras que la familia a través de la fotografía puede reconstruir lo que ella misma configura como su pasado, ubicando la ascendencia que la conforma en la lógica de los árboles genealógicos, y así poder fijar los instantes-rituales que la posibilitan como institución, también ha podido conocerse a sí misma, ha visto paulatinamente su imagen de frente y han sido imágenes tan importantes que se archivan, se miran y se muestran con pasión... ¿Qué sucedía cuando las familias no dominaban ni poseían los medios de la técnica fotográfica, ni los recursos de la pintura retratista? ¿Acaso, no se habían visto jamás reflejadas? Como vemos, los relatos son intrínsecos a los grupos sociales, a los individuos, y tal vez la palabra, las historias de los abuelos en los momentos de ocio permitía a las nuevas generaciones aprehender su propia historia. Es claro que la Modernidad, momento del imperialismo de la imagen, le permitió a la familia burguesa, a la media, a los pobres y campesinos verse, aunque a escalas diferentes, en fotos.

Tal vez si la familia se hubiese enamorado como no lo hiciere otrora Narciso de Eco, al mirar los rituales familiares en las fotografías pareciese que tuvieran acústica, siempre las mismas características visuales; sucede aún más con las poses construidas: se repiten, tienen eco, como si cada individuo tuviera su propia marca-pose y se mostrara inerte frente al objetivo de la cámara. No se puede desconocer que la familia se ha "enamorado" de su propia imagen; sus fotografías son de tan magno agrado que cuando se abre el álbum de cara a visitantes o ante los mismos miembros del grupo se ríe, se recuerda, se llora..., es decir, se manifiestan sentimientos. Cuando nos encontramos con la imagen de un ser amado ausente, pareciera que la foto contuviera al ser mismo; podemos llorar sobre el papel, darle besos a la foto o voltear el portarretratos del amado cuando se le es infiel. Es "la misma labor de Sísifo: subir raudo hacia la esencia y volver a bajar sin haberla contemplado, y volver a empezar" (Barthes, 1990, p. 120). En esto mismo consiste la desgracia de Narciso: ver su imagen en el agua, querer tocarla, besarla, desgarrarla, poseerla, pero únicamente se encuentra con su fastuosa e inmaterial imagen $y$, por tanto, frente a su falsedad y con su realidad.

Al respecto, Eliade (1994) señala:

Un objeto o un acto no es real más que en la medida en que imita o repite un arquetipo. Así, la realidad se adquiere exclusivamente por repetición o participación; todo lo que no tiene un modelo ejemplar "desprovisto de sentido", es decir, carece de realidad (pp. 39-40). 
Esto constituye un trabajo doloroso al que la misma familia incurre al mostrar a los seres que componen su familia, sus antecesores, y únicamente los conoce en la imagen, en la pose, en el pasado, produciendo el falso efecto que se busca: el conocer, el tener presente, el ubicar a los integrantes de la familia como tales, como parientes. La fotografía es ese arquetipo que se repite e insiste en solidificar la imagen de sí; una imagen de la que pueda seducirse, embelesarse, cautivarse en el tiempo; es su sacrificio arquetípico que lo salva de la muerte, pero al mismo tiempo la reitera, en tanto taxidermiza los intervalos esenciales que le son desprovistos de fealdad.

¡Qué hermosa metáfora hablar de la técnica fotográfica como Ovidio describe la fuente de agua que nunca ha sido tocada! El rollo fotográfico contiene sus películas "en blan$\mathrm{Co}^{\prime \prime}$, no han sido tocadas por ningún rayo de luz, y lo primero que refleja es un rostro que queda ante la imagen, una familia que se agrupa inmóvil, con poses "adecuadas", esperando el flash; pero hay una diferencia: a Narciso lo refleja un espejo, agua, sin que fije en el tiempo ni en la materia sus movimientos, la imagen ronda su presente; a la familia la refleja la foto, un "espejo con memoria" -según se le llamaba al daguerrotipo en 1861-, y esta sí que puede inmovilizar la imagen para siempre, ¿para qué?, ¿para recordar?: "Recordar quiere decir seleccionar ciertos capítulos de nuestra experiencia y olvidar el resto" (Fontcuberta, 2004, p. 58).

Pero la imagen en un espejo; sea en el agua o en una cuchara, es totalmente evanescente: la figura no permanece. Cabe anotar que la insinuación de una posible relación o apostasía entre espejo e imagen está en el sentido simbólico en que el espejo devuelve inmediatamente la figura o el rostro que se posa frente a él; una especie de dependencia de la mirada y una correspondencia entre lo que se ve y lo que se mira, entre el que ve y el que se mira; un juego que sucede cuando permanecemos delante de él. Cuando Narciso se observa en su reflejo, no se ve a sí mismo de inmediato, sino que siente que es Otro, y en su afán de palpar tan bella imagen, lo intenta sin conseguir tocarla. El espejo se nos muestra como la verdad y refleja -al simple parecer- la realidad de lo que muestra; de allí surge la falsa sensación de Narciso, o el espejo mágico del cuento de Blancanieves, que tiene vida propia y puede augurar: ¿quién en la tierra es la más bella de todas?: “El espejo nos suministra no solo la pura verdad, sino también la revelación y la sabiduría" (Fontcuberta, 2004, p. 38).

La raíz de la palabra "espejo" la encontramos en el latín speculum: por un lado, specio, que significa "mirar"; por otro, el sufijo $\mathrm{cu}$ lum, que significaría un "instrumento para mirar". Pero, ¿qué tan cerca se encuentra speculum de "especular", siendo que esta última viene del latín specularis, que quiere decir "mirar desde arriba, espiar u observar los astros por medio de un espejo"? Esto nos lleva a la paradoja expuesta por Fontcuberta, en la que se debate una visión aséptica y sobre esta se superpone una visión especulativa, lo que llama al entendimiento del espejo no como entidad ontológica, sino como "rutina cultural", en el sentido de que la relación entre objeto y reflejo está mediada por otra palabra de la familia: por los espejismos. Sabemos que un espejo anula la tridimensionalidad e invierte la imagen; algunos nos hacen ver gordos, cabezones, espejos que están más cerca de la fantasía que de la realidad. De esta manera, pensar en el espejo como cámara fotográfica es pensar 
en los filtros culturales, políticos, científicos, etc., como también en los filtros discursivos que adecúan la marca en la imagen por sus intenciones de uso.

Si Narciso muere por ver su imagen, los vampiros -trágicamente- no se ven en los espejos: carecen de reflejo. El primero experimenta la pulsión de muerte al amar ese otro que es su propio reflejo envuelto en "la seducción de lo real", y el segundo, la frustración del deseo de mirarse, la presencia sin espectro, no tendrá la certeza de saberse, reconocerse en la imagen, que conformaría el cuadro esquizoide en tanto no hay identificación con la imagen del otro:

\section{Es fácil imaginar la paradoja -jel supli- cio!- de un narciso-vampiro: alguien que persigue el reflejo del que carece: narcisos y vampiros son metafísica- mente contrarios. De alguna manera, un diagnóstico posible sobre la foto- grafía contemporánea podría ser el anuncio de la abrupta irrupción de los vampiros, su proliferación, su coexis- tencia con los narcisos $\mathrm{y}$, a menudo, la progresiva metamorfosis de unos en otros (Fontcuberta, 2004, p. 41).}

$\mathrm{Al}$ entender la disputa latente y manifiesta entre espejo y fotografía, se hace posible incluir el factor tiempo: mientras que el primero imprime el reflejo en la facticidad del presente, siendo su naturaleza la de traslucir el instante del ahora, careciendo de memoria -este no tiene archivo, pues replica instantáneamente los mismos movimientos que hace su reflejo, por lo que así somos el reflejo de un espejo-, con la fotografía se pelea la urgencia de fijar el presente, pero no lo logra: se convierte en pasado, condena a la reminiscencia, es el juego de disparar una foto y agarrar un presente que se desdibuja, que se desvanece cada vez más rápido.
Pensar en la tragedia de Narciso permite afirmar que la práctica fotográfica de la familia tiene características de narcisismo, es decir, hay una búsqueda -no siempre conscientepor encontrar el reflejo de sí mismo, que al igual que Narciso es su aproximación a la muerte, al suicidio. Entendámoslo así: la fotografía no es más que la ratificación de lo que ha sido y solo adquiere el valor -quiérase de veracidad y también de dolor-en la medida en que con la imagen fija hay una desaparición irreversible del sujeto, del momento, del tiempo que se le esfuma; es la certeza de la muerte del instante irrepetible. Fotografiar pasa por ese intento por captar lo que nos es significativo, en un presente que va muriendo segundo a segundo, que se escapa a una velocidad tal, que hay que fijarlo en pasado, porque la fotografía ante todo está en tiempo pasado: revela lo que se ha fundido en los días, en la muerte de los días. La fotografía se ha consolidado como el instrumento privilegiado de la memoria social, poseyendo la fuerza de reavivar indisociablemente la memoria de lo desaparecido, de su inminente desaparición, y es recordar que en algún momento han estado vivos y reafirmar que están muertos y enterrados.

Con los diferentes relatos de Narciso se recoge paralelamente su destino mortal en el funesto momento en que se viese a sí en la imagen, una condena, quizá por su frustración que le produce la ausencia de otro digno de ser amado, digno de ser visto. Por eso, conceptos como "lo mismo y lo otro", "identidad y alteridad" o si se quiere "mismidad y otredad" (Caballero, 2003, p. 117) se ponen en juego algunas veces en una discordia, otras en diálogo, para resolver ciertas disyuntivas complejas en lo que tiene que ver con que el objeto del deseo es el Otro que es el desdoblado del mismo ser, y 
revalidar ese impedimento de cohabitar, de tener, de poseer al ser amado de otro modo que no sea por la visión. Esta es la misma condición de la práctica socializante del álbum de familia, en el que se muestran los antepasados a las nuevas generaciones: sus héroes, sus mitologías, sus relatos, su pasado legítimo y colectivo que lo ubica en el tiempo, en la clase social, en las estéticas y maneras de convivir, y que estas sean mostradas en fotografía, contadas muchas veces verbalmente, adquieren el estatus de verdad por el hecho de tener la prueba fidedigna que demuestra la historia: la historia prensada en imagen.

De este modo, existe una necesidad intrínseca a las formas familiares, a su ser social, a saber: entreverse en su mejor pose, con la mejor vestimenta, en los momentos gratos, percibirse como órgano institucionalizado que se mira a sí para construir una imagen referente ante la sociedad y erigir su propia mitología (relato) con los elementos imaginarios que le presta la técnica, donde salte a la vista una moralidad y una belleza aceptada. En su punto de partida, y digamos también de llegada, el narcisismo no sería un enamoramiento (para la familia, digamos deseo de representación) de sí mismo, sino de Otro que luego se entenderá como duplicado de sí mismo, y que a la inversa sería la negación del Otro, del olvidado, de inmoral, del que se oculta, del reverso de la foto, de lo que no se quiere ni se puede mostrar de sí, de su imposibilidad de poseerlo; hace referencia al que no se quiere ni se puede ser: la parte odiada de sí, muy cercana a su contrario.

Fotografiar es una de las maneras para reinventar lo real, también para reinvertirlo -en la medida que emplea los beneficios que le da la imagen para aumentar el capital de la representación visual-; es una licencia para extraer del mundo cotidiano las imágenes de sí, imágenes que le sirven a su discurso de institución, el beneplácito de la mnemotecnia selectiva y el consentimiento para olvidar.

Si lo pensamos de este modo, entraría en conflicto una confusión -la misma de Narciso- entre la realidad y el reflejo, entre la ficción y lo real: ¿apariencia o huella?, ¿mentira o indicio? Sin estos pares dialécticos, sería muy difícil desenmarañar la trama del espejo y la fotografía, al igual que la del relato fotográfico y la de la imagen amorosa de Narciso, como también la naturaleza discursiva que pone a hablar a la imagen en pro de unos ejercicios particulares de control en el armazón de los relatos legítimos.

La fotografía se nos muestra comúnmente como el instrumento inequívoco para fijar el mundo que vemos, y es así como nos damos la patente para sentir que lo que vemos en las fotos es la verdad, pero caemos en la decepción narcisista -casi de manera inconsciente- de creer que en la imagen está lo real, que se ha logrado capturar con la objetividad que permite la cámara el mundo del afuera, el Otro.

$Y$ es que se trata de lo obstinada que resulta ser la fotografía, al mostrar que el referente, el que se captura por los rayos de la luz, siempre está ahí, intacto, "inmóvil como una estatua de mármol", inservible. Con el soslayo del doble -del que habla Barthes-, la terrible traición del acto hipócrita al que se refiere Fontcuberta y el memento mori de Sontag se construye, entonces, un triángulo analítico para ubicar a la fotografía, a su naturaleza, en el juego de la identidad y la alteridad, entre la relación ilusoria de la apariencia y la realidad, entrando en el mismo "error de Narciso [...], en una suerte de 
progresión que opera desde la belleza simplemente observada hacia su carácter engañoso" (Tola, 2006, p. 115). Se trata aquí de desmitificarla en el sentido de desmontar su encarnación falaz en la vida y en la verdad, estando más ligada a sus contrarios: a la muerte y a la mentira.

Entendiendo que la cámara fotográfica es un artefacto para la captura de lo que está desapareciendo, analogía que se hace entre el fotografiar y el disparar un arma de fuego, siendo las dos igualmente fáciles de operar, Sontag (2001) plantea:

Hay algo depredador en la acción de hacer una foto. Fotografiar personas es violarlas, pues se las ve como jamás se ven a sí mismas, se las conoce como nunca pueden conocerse; transforma las personas en objetos que pueden ser poseídos simbólicamente. Así como la cámara es una sublimación del arma, fotografiar a alguien es cometer un asesinato sublimado, un asesinato blando, digno de una época triste, atemorizada (p. 31).

Con Barthes existe -en la fotografía- una insistencia obstinada en repetir lo que nunca más se podrá repetir, un eterno retorno a la mirada de la muerte, al instante que ahora es muerte; por eso, cuando se toma una fotografía, "vivo entonces una microexperiencia de la muerte (del paréntesis): me convierto verdaderamente en espectro" (Barthes, 1990, p. 46).

\section{Del Narciso al Narcisismo Y LA ETAPA DEL ESPEJO. Aproximación al PSICOANÁLISIS}

Las instancias psíquicas fundamentales deben concebirse, en su mayor parte, como representantes de lo que sucede en un aparato fotográfico: es decir, como las imágenes, virtuales o reales, producidas por su funcionamiento.

Lacan, 1990

En la Introducción al narcisismo (1914), Freud concibe a este como la expresión en la que el individuo toma como objeto sexual su propio cuerpo, lo ama, lo acaricia y en el que puede llegar a completar la satisfacción. Sin embargo, no se queda con esta conceptualización tomada de una descripción clínica de 1899, sino que profundiza en sus expresiones, características y localizaciones en el sujeto.

Mencionaremos solamente algunas aseveraciones -que se hacen desde el psicoanálisis en este campo- que nos permitan extrapolar el problema del mito de Narciso y su relación con la fotografía, el espejo y la familia.

Uno de los elementos fundamentales para entender qué concibe Freud por narcisismo es su correspondencia directa con un "autoerotismo" como acto psíquico y corporal, en el que el individuo se ve envuelto en un yo ideal que busca el amor ególatra, pero también en la búsqueda libidinosa del otro en representación de sí mismo, presente en psicopatologías y en normalidades individuales.

Una expresión manifiesta es la relación entre el sujeto y su objeto del deseo en donde 
estos aparecen fusionados, una patología en donde el objeto se ve materializado en el sujeto y el suicidio es la culminación de la pulsión de muerte. Al igual que en el mito, se mata al objeto, pero lo que realmente muere es el sujeto: se ama al objeto, pero al que verdaderamente se ama es al sujeto.

Si nos detenemos en la formación del yo ideal en el sujeto que busca su realización en la representación de sí, como deber moral, en la participación de una construcción de "autorrepresentación", en el sentido de una observación vigilante y reprobativa, de júbilo y completud, que para el psicoanálisis se construye en lo inconsciente, ello da cuenta del movimiento de identificación en el otro, que puede ser su propia imagen o la madre (entendida esta como su función), en donde el drama gira en torno a que el yo es yo en tanto es otro.

Nos encontramos en la práctica fotográfica cotidiana, corriente, sin ánimo estético, con un interés (oculto) en mostrar-se y fijar al sujeto en la imagen como se lo permiten sus motivaciones, sentimientos o moralidades; nos encontramos con la fabricación de poses, escenarios, encuadres y repeticiones que moldean ese yo ideal, que lo materializan, que lo erigen en la película. Entonces, el movimiento del yo ideal en Freud tiene la función de contribuir a la formación del yo, gracias a la confusión que genera identificarse en el otro, pudiendo desencadenar en el cuadro psicótico típico de la muerte de Narciso: fundirse en su propia imagen y creer que en ella está su amor hasta morir ahogado. Esta estructura patológica es propicia a causa de la no introducción de otra de las etapas en la constitución del sujeto: el ideal del yo, que tiene que ver con la emergencia del elemento del lenguaje, la prohibición, la historia y la cultura, permitiendo pasar por el escenario del yo ideal y no sucumbir en él, para suceder en la muerte simbólica instalada por el lenguaje.

La primera etapa que hemos descrito del yo ideal en Freud, para Lacan sería lo imaginario, y el ideal de yo, lo simbólico; diada a la que el psicoanalista francés le adicionaría la categoría de lo real, para completar el anillo que conforma la realidad.

El registro de lo imaginario en Lacan tiene que ver con el instante en que sucede la identificación en la imagen, que a simple vista refleja los visos ilusorios de un encuentro con un organismo completo, unido, sin fisuras, al que sucede una actitud de felicidad al adquirir la sensación de ser un individuo o colectividad total, que se manifiesta a partir de la dialéctica de la influencia exterior/interior, ellos/nosotros, bueno/malo, etc., identificándose con una imagen donde no aparece la falla por ningún lado.

Es claro que la fotografía familiar permite la inserción de imágenes de la familia perfecta, unida, sin grietas ni conflictos, dándose licencia para construir su propio perfil en el que se identificaría como ente atravesado por la felicidad: el álbum o cualquier compendio de fotografías de familia -valen también las imágenes del recuerdo que se solidifican por la presencia de una foto- es ante todo un lugar de mirada que secciona los momentos e intenta monopolizar el recuerdo. Esta selección del suceso-dignode-fotografiar es el ángulo que permite la mirada especular que presenta Lacan (1990) como "esquema de los dos espejos". El autor afirma que la cámara fotográfica serviría como analogía para entender el funcionamiento de la psiquis en el aprendizaje y recepción de imágenes. 
En este esquema óptico representa la función visual que tiene la colocación de dos espejos: uno cóncavo y otro plano para lograr la visión ordenada de objetos que están desubicados; pero por el mismo establecimiento del ojo que mira y los ángulos de los espejos, se organiza lo descompuesto $\mathrm{y}$ adquiere la lógica que se necesita. En el orden de lo imaginario se establece un cierto acomodo de lo real, de lo desordenado y desproporcionado por naturaleza. Así, si a la estructura familiar la signa el conflicto, la disputa, el desamor, los problemas y la desunión, el aparato fotográfico funcionaría, en primera instancia, como dinamizador de una imagen especular que permite la unión, la completud y la felicidad esporádica, en la que se lucha por el mantenimiento del vínculo y la identificación en su propia fantasía manifiesta en las poses rituales del flash.

Este primer escenario narcisista en el registro de lo imaginario es llamado por Lacan (1999) narcicismo primario, que nosotros llamaremos en este texto narsicismo, categoría que representaría la tragedia del Narciso, ya que este le imprime a la imagen, a su propia imagen, que-no-es-él-pero-él-no-lo-sabe, la fuerza de su identificación en el otro, tratándola bajo el enamoramiento, desencadenando en la actitud mortífera de la pulsión de traspasar y obtener ese objeto del deseo escurridizo y evanescente.

La memoria, en lo que tiene que ver con los procesos de identificación -sean subjetivos o sociales- en los que la forma de un yo o un nosotros se construye a partir de las imágenes binarias que representan una colectividad sólida y completa, siendo la historia de las identificaciones imaginarias la fabricante un relato de unidad, que funciona en la familia por medio del álbum o compendio de fotografías, y de la narración discursiva que hila, solidifica y trabaja con la imagen que prensa el pasado.

En este nuevo escenario ocurre la inmersión en el lenguaje -que Lacan llama lo simbólico y Freud el ideal del yo-: de una identificación imaginaria en el otro, donde actúa el narciso 1, se desliza al narciso 2, es decir, del escenario donde la imagen especular, fotográfica, mental o mítica adquiere el estatus del pequeño-objeto-del-deseo, queriéndose fundir en él, en el circuito mortífero de traspasar el espejo, que al no sucumbir bajo la atracción fantasmática que ejerce traspasar el espejo y pervivir bajo un ideal de completud y felicidad, se da la posibilidad de la penetración en el lenguaje e incurrir en la posibilidad de contar con la historia y la impronta de la prohibición. Este momento es llamado como el narciso secundario, que le permitiría a la fotografía o a cualquier tipo de identificación especular romper con la cadena imaginaria de la fantasía de totalidad e introducir la falla en lo simbólico.

A la fotografía familiar la acompaña un relato, un discurso que la cuenta, que la ubica en el espacio y en el tiempo, que selecciona unos personajes, unas vivencias, unas historias, fija unos rituales, revive el recuerdo..., insta a sus miembros y las visitas hogareñas a participar en el ritual de ver y escuchar las fotos. Es así como en este tipo de fotografía se permite la inserción del lenguaje; sin embargo, el problema radicaría en lo siguiente: con el discurso en verdad, ¿en la familia se da la posibilidad de incluir la falla, los problemas, las fracturas inherentes a este grupo social? ¡Creeríamos que no! La adherencia en la imagen de los momentos dignos de fotografiar -contemplándolos también en su silencio, en su exclusión, en 
lo no merecedor de convertirse en historia, en pasado- pondría a la familia en la encrucijada de seguir viviendo bajo la fantasía que expresa su fotografía y morir en el relato de una historia feliz, donde todo está bien y se posa igual que el ritual fotográfico en donde la ocultación de la fisura se hace con mueca de sonrisa, por un lado, o permitirse romper ese cristal y convivir enfrentando el error, fallando cada vez mejor en el acuerdo y el límite, jugando entre la prohibición y la felicidad fugaz, rompiendo fantasías que la instan a fundirse en su espejo de memoria.

La tragedia familiar del narciso 1 es la misma de Narciso: la de creer que en su imagen se prensa el objeto-objeto de su identificación, de su amor, de su realidad, de su deseo de obtener una familia unida y radiante, de demostrar fugazmente la obtención de logros, triunfos y trofeos sociales, políticos, económicos y religiosos celebrados por la cultura; su tragedia pendula en hundirse en su imagen historizante y fantasiosa del éxito colectivo, y morir en ella sin soportar el fracaso inherente, trabajando para tejer su camuflaje...; y es la fotografía una de esas mordazas camaleonescas que contribuye a evidenciar la frustración de la imagen de la familia feliz llevada a lo real, en tanto hay que tener ojos y buena luz para ver su negativo: una visión del positivo -en elucidación de indicio- en tanto segmenta y oculta.

\section{Epílogo}

El yo fotográfico -parodiando a Freud- es la materialización de ese ideal del yo que se enriquece con las satisfacciones logradas por medio de la imagen, de esa cosa que se muestra como objetiva e inalienable en el cumplimiento del ideal de autorepresentación:
Del ideal del yo parte un importante camino para la comprensión de la psicología colectiva. Este ideal tiene, además de su parte individual, su parte social: es también el ideal común de una familia, de una clase o de una nación (Freud, 2005, p. 37).

Es así como se abre el espectro de entendimiento al rumiar en torno a la categoría ideal del yo y de la alienación en el narciso 1 y el narciso 2 , en vista de aquellos prototipos -conscientes o inconscientes- de los que se arman las familias, los individuos, los políticos, la publicidad y la prensa, para figurarse en la imagen, para contemplarse a sí misma y mostrarse ante los demás, en el ajuste de la estructura de su ideal de yo. Un arquetipo que obedece a filtros sociales, de clase, históricos y estéticos, al igual que a sus motivaciones e intereses como unidad de grupo, como sujeto social, como interesado en una campaña política, en la venta de algún producto o en la fabricación del amarillismo. Entonces se juega el fenómeno de verse a sí mismo, al advenimiento del yo mismo como otro, que Barthes (1990) llamaría "la disociación ladina de la conciencia de identidad" (p. 44). Nuevamente se discute que el sujeto se convierta en objeto $\mathrm{y}$ ese objeto se convierta en substancia de sus deseos, en el sentido de conectarse más con las nostalgias, los amores, las tristezas, las pasiones. Prueba más tangible en la fotografía pornográfica y sus efectos libidinosos: es tan capaz de sustituir al sujeto de hueso y pellejo, y conformarse y permitirse el goce con un objeto que transporta al voyeur, a la culminación de su deseo.

Cavilando la conclusión en clave cíclica, contradictoria -o trágica, si se prefiere-, el mito de Narciso ha permitido entablar controversias y dispares lecturas, de cara a 
fenómenos literarios, culturales, patológicos, sociológicos y estéticos de la sociedad moderna, fertilidad inherente a la producción clásica griega de mitos y relatos teogónicos, que cada vez están más cerca de nuestras realidades, tragedias cotidianas y heridas históricas.

Si entendiésemos la fotografía como el intento narcisista moderno de erigir un monumento antropocéntrico, donde se malogre la mirada a la naturaleza, dilucidamos, entonces, las pistas para entender el fenómeno de fijar-nos en el papel, lo que también permite analizar una posible historia de las miradas donde maquillamos nuestra estancia temporal y la hacemos aprehensible. Una máscara estructural tendente a ser configurada por los filtros que nos hacen únicos e irrepetibles, que lucha por la estandarización de la visión, de lo que consideramos comúnmente como realidad. Una mirada social que se refina en tanto se sirve de mecanismos para hacerla hablar en pro de un discurso cualquiera, ya sea a favor del consumo desmedido de aparatitos, ratificar falacias políticas y judiciales, punzar el corazón disecado del invidente actual al mostrarle imágenes de los desgraciados y desposeídos del mundo, permitirle a la banalidad un yo fotográfico trivial prensado en los límites difusos de la arena global.

\section{RefERENCIAS}

Barthes, R. (1990). La cámara lúcida. Buenos Aires: Paidós.

Borges, J. L. (2011). Inquisiciones. Otras inquisiciones. Bogotá: Random House Mondadori.

Caballero, M. E. (2003). El mito de Narciso en la poesía de Cernuda. Revista Circe, 8. La Pampa: Universidad Nacional de la Pampa, Instituto de Estudios Clásicos, Facultad de Ciencias Humanas.

Eliade, M. (1994). El mito del eterno retorno. Barcelona: Altaya.

Fontcuberta, J. (2004). El beso de Judas. Fotografía y verdad. Barcelona: Gustavo Gili.

Freud, S. (2005). Introducción al narcisismo y otros ensayos. Madrid: Alianza.

Lacan, J. (1990). El seminario de Jacques Lacan. Libro 1. Los escritos técnicos de Freud, 1953-1954. Buenos Aires: Paidós.

Olalquiaga, C. (1993). Megalópolis. Caracas: Monte Ávila Editores.

Ovidio (2007). Las metamorfosis. Madrid: Alianza.

Pausanias (1994). Descripción de Grecia, libros VII-X. Madrid: Gredos.

Sontag, S. (2001). Sobre la fotografía. Barcelona: Alfaguara.

Tola, E. (2006). "Sic amet ipse licet, sic non potiatur amato" (ov., met. iii, 405): Narciso en las redes de la inversión. En versión electrónica de la Revista de Estudios Clásicos, 33. Mendoza: Universidad del Cuyo. Recuperado de https://dialnet.unirioja.es/servlet/fichero_articulo?codigo $=3426746 \&$ orden $=0$ 